2013

\title{
Maryland's Family Divisions: Sensible Justice for Families and Children
}

Barbara A. Babb

University of Baltimore School of Law, bbabb@ubalt.edu

Follow this and additional works at: http://scholarworks.law.ubalt.edu/all_fac

Part of the Family Law Commons, and the Judges Commons

\section{Recommended Citation}

Maryland's Family Divisions: Sensible Justice for Families and Children, 72 Md. L. Rev. 1124 (2013)

This Article is brought to you for free and open access by the Faculty Scholarship at ScholarWorks@University of Baltimore School of Law. It has been accepted for inclusion in All Faculty Scholarship by an authorized administrator of ScholarWorks@University of Baltimore School of Law. For more information, please contact snolan@ubalt.edu. 


\section{MARYLAND}

LAW REVIEW

MARYLAND'S FAMILY DIVISIONS:

SENSIBLE JUSTICE FOR FAMILIES AND CHILDREN

Barbara A. Babb

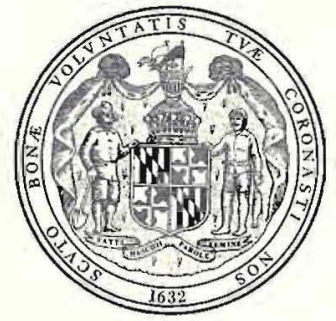

UNIVERSITY OF MARYLAND 


\title{
MARYLAND'S FAMILY DIVISIONS: SENSIBLE JUSTICE FOR FAMILIES AND CHIIDREN
}

\author{
BARBARA A. BABB*
}

In January 1998, the judges of the Court of Appeals of Maryland signed Rule 16-204 ${ }^{1}$ and formally launched the process of family justice system reform in Maryland. During the ensuing fifteen years, Maryland became a national model in this area. These changes and improvements occurred largely because of the inspirational leadership of Chief Judge Robert M. Bell, a man owed a debt of gratitude by everyone involved in family law proceedings, including families, children, attorneys, judges, court personnel, and services providers, among others.

This Tribute honors Chief Judge Bell by contextualizing the enormity of the process and outcomes resulting from his guidance and oversight. It will begin in Part I by identifying the causes underlying the impetus and need for family justice system reform in Maryland. Part II will explain what Maryland Rule 16-204 does, the process surrounding implementation of the rule, and the mechanism for continued oversight of the state's family justice system. Part III will then describe the impact of the reform effort. The Tribute will conclude with a glimpse into the future and likely evolutions affecting Maryland's family justice system.

\section{WHY DID MARYLAND NeEd FAMILY JUSTICE SYSTEM REFORM?}

During the late 1980s and early 1990s, two formal study groupsthe Governor's Task Force on Family Law and the Advisory Council on Family Legal Needs of Low Income Persons-analyzed Maryland's body of family law and the legal system within which it operated. In their final reports, each group identified problems with Maryland's existing family justice system and endorsed the creation of a unified

\footnotetext{
Copyright $(2013$ by Barbara A. Babb.

- Associate Professor and Director, Sayra and Neil Meyerhoff Center for Families, Children and the Courts, University of Baltimore School of Law.

1. MD. R. 16-204.
} 
family court ${ }^{2}$ for Maryland, or a single state tribunal with comprehensive subject-matter jurisdiction over cases arising from family breakups and those involving the status of children. Statistical data about family law case filings in Maryland confirmed the critical importance and dominance of this area of law. During fiscal year 1989-1990, domestic cases (not including juvenile matters) represented fifty-two percent of all circuit court filings. ${ }^{3}$ The two study groups found that delay, inefficiency, duplication, fragmented jurisdiction, lack of coordination, lack of uniformity, lack of finality, lack of judicial interest and expertise in family law, and lack of access to the justice system, particularly for unrepresented and low-income litigants, all characterized the structure for resolving domestic disputes. ${ }^{4}$

Representatives from both study groups conducted exhaustive background research about and made site visits to several states with unified family courts. ${ }^{5}$ As a result of these efforts, both study groups recommended changes to Maryland's family justice system. They advocated for the creation of a single court with independent facilities and staff and empowered with comprehensive subject-matter jurisdiction over the full range of family law cases, including delinquency and dependency. ${ }^{6}$ They also urged that case management techniques assign a judge with expertise in domestic matters to remain on a case from start to finish. ${ }^{7}$ Finally, representatives of the study groups recommended that a family court offer certain services, such as mediation, and coordinate with other service providers within the community to address litigants' non-legal needs, such as domestic violence, substance abuse, and mental health issues, among others. ${ }^{8}$ In states with family courts, this system reduced duplicative proceedings and inconsistent orders, saved time and money for the parties and the state, resulted in greater litigant satisfaction, and enabled a holistic approach to family legal problems. ${ }^{9}$ Further, " $[\mathrm{t}]$ he family court con-

2. For a comprehensive explanation of the unified family court concept, see Barbara A. Babb, Fashioning an Interdisciplinary Framework for Court Reform in Family Law: A Blueprint to Construct a Unified Family Court, 71 S. CAL. L. REV. 469 (1998).

3. MD. JUDICIARY ANNUAL REPORT 47 (1989-90).

4. See generally Barbara A. Babb, Family Court for Maryland: The Time Has Come, $25 \mathrm{MD}$. B.J. 16 (1992).
5. Id.
6. Id.
7. Id.
8. Id.
9. Id. 
tributed to the recognition of domestic disputes as important and deserving of independent, unique treatment.."10

For the better part of the 1990s, family court advocates, including concerned citizens, family law attorneys, bar leaders, mediators, services providers, legislators, legal scholars, and the Maryland Attorney General, appeared annually before the Maryland General Assembly, including both the House of Delegates and the Senate, to testify in favor of proposed family court legislation and the recommendations for reform discussed above." While the proposed legislation often passed by an overwhelming majority in the House of Delegates, it never was called to a vote in the Senate Judiciary Committee; thus, it never was introduced on the Senate floor. Nonetheless, in 1996, the General Assembly passed legislation funding a pilot program family division in the Circuit Court for Baltimore City. ${ }^{12}$

Shortly after Chief Judge Bell's appointment in 1996, a handful of advocates supporting the creation of a family court met with him to explain the need for family justice system reform, the proposed legislative solution, and obstacles interfering with the passage of the legislation. After devoting a few weeks to study and understand the issues, Chief Judge Bell called the advocates together. He said the concepts in the proposed legislation made sense and that implementing this type of family justice system reform was the right thing to do. He gave the advocates his word that, if the proposed legislation failed, he would work to create a court rule to accomplish the same or similar results.

Indeed, due to some minor issues, the proposed legislation failed during the 1997 session of the Maryland General Assembly. True to his word, Chief Judge Bell that summer directed the Standing Committee on Rules of Practice and Procedure, along with a few individuals specially appointed to the committee, to begin work crafting a court rule designed to create a family division as part of the circuit court system. The Rules Committee's efforts resulted in the proposed Maryland Rule 16-204, signed by the judges of the Court of Appeals in January 1998, creating Maryland's family divisions. ${ }^{13}$

10. Id. at 19 .

11. See S.B. 571, 411th Leg. (Md. 1997); H.B. 1346, 411 th Leg. (Md. 1997); H.B. 18, 410th Leg. (Md. 1996); S.B. 493, 409th Leg. (Md. 1995); H.B. 644, 409th Leg. (Md. 1995); H.B. 1172, 408th Leg. (Md. 1994).

12. See S.B. 160 , ch. 13, 410th Leg. (Md. 1996) (restricting $\$ 140,000$ to establish a pilot program family division in the Circuit Court for Baltimore City).

13. MD. R. 16-204. 


\section{WHAT ARE MARYLAND'S FAMILY DIVISIONS?}

Maryland Rule 16-204 authorizes the creation of a separate family division of the circuit court in jurisdictions with more than seven resident judges. ${ }^{14}$ Those jurisdictions presently include Anne Arundel County, Baltimore City, Baltimore County, Montgomery County, and Prince George's County. The rule grants the family divisions comprehensive subject-matter jurisdiction over the following types of cases: divorce, annulment, and property division; custody and visitation; alimony, spousal support, and child support; paternity, adoption, termination of parental rights, and emancipation; criminal nonsupport and desertion; name changes; guardianship of minors and disabled persons; involuntary admission to state facilities and emergency evaluations; family legal medical issues; domestic violence actions; juvenile causes, including delinquency and dependency; and civil and criminal contempt. ${ }^{15}$

Critical to the effective resolution of most family legal proceedings is an attempt to address any related underlying non-legal issues by providing or connecting the parties with supportive services. ${ }^{16}$ Rule 16-204 addresses these services in two ways. First, it mandates that the family divisions provide certain services, including mediation, custody investigations, emergency response personnel, mental health and substance abuse evaluations, information services with assistance for unrepresented litigants, lawyer referral services, and parenting seminars. ${ }^{17}$ Second, the rule requires the appointment of a family support services coordinator by the County Administrative Judge in each family division to compile available community-based support services, coordinate those services with the family division, and report to the County Administrative Judge on the need for additional services. ${ }^{18}$

For each family division, the County Administrative Judge also has the responsibility to ensure that cases are heard expeditiously, meaning that appropriate judicial resources must be assigned to the family division. ${ }^{19}$ To support this process, the County Administrative Judge also must identify cases within the family division that should be

14. MD. R. 16-204(a) (1).

15. MD. R. 16-204(a) (2) (A-M).

16. Barbara A. Babb, An Interdisciplinary Approach to Family Law Jurisprudence: Application of an Ecological and Therapeutic Perspective, 72 IND. L.J. 775 (1997).

17. MD. R. 16-204(a) (3) (A-H).

18. MD. R. 16-204(a) (4) (C) (i-iii).

19. MD. R. 16-204(a) (4) (A). 
assigned to one judge for the entire case. ${ }^{20}$ Finally, the County Administrative Judge annually must prepare and submit to the Chief Judge of the Court of Appeals a written report describing the family support services needed by the family division, an estimate of the cost of these services, and an estimate of the jurisdiction's financial need relative to the services. ${ }^{21}$

Maryland Rule 16-204 also addresses certain aspects of family law case handling in those many circuit courts without a family division, or those courts having less than eight resident judges. ${ }^{22}$ The rule requires that, subject to the availability of funds, certain family support services be available, including mediation, custody investigations, personnel to respond to emergencies, mental health and substance abuse evaluations, information services with assistance for self-represented litigants, lawyer referral, and parenting seminars. ${ }^{23}$ Further, the County Administrative Judge in these circuit courts is required to appoint a full- or part-time family support services coordinator, whose responsibilities are the same as those for this position within the family divisions. ${ }^{24}$ Finally, the County Administrative Judge in jurisdictions without a family division also is required annually to prepare and submit to the Chief Judge of the Court of Appeals the report described above. ${ }^{25}$

Immediately after the authorization of Maryland Rule 16-204, Chief Judge Bell formed the Ad Hoc Committee on the Implementation of Family Divisions. The group included judges, court administrators, and an academic. The committee charge was to begin the strategic planning process for the judiciary as it operated according to the dictates of the new rule. Also instrumental in this process was the Committee of Family Law of the Maryland Judicial Conference.

One of the first steps in the strategic planning process was the creation of a mission statement and the identification of system values, both intended to guide the operation of Maryland's family justice system. In October 1999, the mission statement emerged:

The mission of Maryland's Family Divisions is to provide a fair and efficient forum to resolve family legal matters in a problem-solving manner, with the goal of improving the lives of families and children who appear before the court.

20. MD. R. 16-204(a)(4) (B) (ii).

21. MD. R. 16-204(a) (4)(D).

22. MD. R. 16-204(b) (1).

23. MD. R. 16-204(b) (2).

24. MD. R. 16-204(b) (3).

25. MD. R. 16-204(b) (4). 
To that end, the court shall make appropriate services available for families who need them. The court also shall provide an environment that supports judges, court staff and attorneys so that they can respond effectively to the many legal and nonlegal issues of families in the justice system. ${ }^{26}$

Family justice system values and intended outcomes also were identified and included the following:

Preserving the rule of law $[\mathbf{s}]$ tabilizing families in transition; [p]roviding forums for prompt conflict resolution[; p]romoting co-parenting relationships[; f]ostering parents as primary family decision-makers $[; \mathrm{m}]$ aximizing the use of alternative dispute resolution methods and programs[; p]roviding safety and protection[; p]reserving family relationships where possible[; s] upporting linkages between resource needs and available resources on behalf of parents and their children[; i]ncreasing access to the family justice system [; u]sing judicial time efficiently by providing comprehensive information to judges and masters to assist them in making the most informed decisions possible[; d] eveloping a familiarity with each family[; and i] ncreasing cultural competency[.] $]^{27}$

Over the course of the next few years, the Ad Hoc Committee on the Implementation of Maryland's Family Divisions worked diligently to design a plan to measure the effectiveness of this family justice system reform effort. Guided by the Bureau of Justice Assistance's Trial Court Performance Standards and Measurement System, ${ }^{28}$ the Committee's efforts ultimately resulted in the development and publication of Performance Standards and Measures for Maryland's Family Divisions ("Performance Standards"). ${ }^{29}$

The Performance Standards are based on the five major areas of trial court performance identified by the Bureau of Justice Assistance: access to justice; expedition and timeliness; equality, fairness and integrity; independence and accountability; and public trust and confidence. ${ }^{30}$ In Maryland's document, each standard is described general-

26. Barbara A. BabB \& JefFrey A. Kuhn, PERformance Standards AND Measures FOR MARYLAND'S FAMILY DIVISIONS 6 (2002).

27. Id.

28. Bureau of Justice assistance, DeP'T of Justice, NCJ 161569, Trial CourT PERFORMANCE STANDARDS AND MEASUREMENT SYSTEM (1997), available at https://www.nc jrs.gov/pdffiles1/161569.pdf.

29. BABB \& KUHN, supra note 26.

30. Id. at 6 . 
ly, followed by issues related to implementation of the standard and practical recommendations for judges and masters. In addition, the Performance Standards outline a comprehensive measurement system to chart a specific course to determine whether implementation of the standard is successful. ${ }^{31}$

Chief Judge Bell, in his preface to the Performance Standards, described their utility. He wrote:

The Performance Standards and Measures represent the values which inspired the creation of Maryland's family divisions, and offer a blueprint for future development. They represent the high standards to which we hold ourselves in serving Maryland's families, and the standard to which we expect others to hold us. The AOC [Administrative Office of the Courts] will be developing evaluation tools and protocols based on these Standards to assist the Judiciary in evaluating its performance. We look forward to the challenges these Standards represent. ${ }^{32}$

Indeed, the newly created Department of Family Administration within the Administrative Office of the Courts wrote and published detailed and comprehensive annual reports based on the Performance Standards from 2002 until 2006. ${ }^{33}$ To assist with these reports, each jurisdiction submitted quarterly and annual reports about the family divisions and family services programs. The Department of Family Administration then compiled an Annual Report of the Maryland Circuit Court Family Divisions and Family Services Programs. The reports provided very rich information about the operation of Maryland's family justice system, including many categories of helpful statistics and recommendations for the following year.

\section{WHAT IS THE SIGNIFICANCE OF MARYLAND'S FAMILY JUSTICE SYSTEM REFORM?}

Maryland now explicitly approaches family law decision-making in a therapeutic, holistic, and ecological manner. ${ }^{34}$ Chief Judge Bell has articulated the need for this approach:

31. Id. at 7 .

32. Id. at 4 .

33. Annual Reports, DEP'T OF FAMILY ADMIN., MD. JUDICLARY, http://mdcourts.gov/ family/ (last visited May 23, 2013). Staff changes within the Department of Family Administration have resulted in a lag in the publication of the annual reports. Publication is expected to resume in the near future.

34. BABB \& KUHN, supra note 26 , at 48. 
[W] $\mathrm{e}$ have finally come to realize, that the effective resolution of legal disputes within a family requires a fundamental shift from the traditional adjudication focus to a more holistic, therapeutic model that attempts to improve the lives of families and children in substantive ways. To achieve this new paradigm, there must be a confluence of access to coordinated and comprehensive legal and social services, efficient case processing and management, and a more widely accessible court system. ${ }^{35}$

What, then, is meant by this "holistic, therapeutic model" to resolve family law disputes? A holistic and ecological approach supports the following objectives: Accounting systematically for competing influences on families' and children's lives by means of an ecological approach to family law decision-making, which can help courts pursue strategies designed to establish and to strengthen connections among these influences and can enhance families' and children's functioning. As Chief Judge Bell has commented, this is a "new paradigm" in family law adjudication. ${ }^{36}$ The need for this approach is clear, and the approach itself is sensible.

Further, "[a] therapeutic approach to family law decision making involves resolving legal disputes with the aim of improving the lives of families and children and maximizing the potential positive outcomes of court intervention." ${ }^{37}$ Since the creation of Maryland's family divisions in 1998 and the commencement of the family justice system reform effort, countless numbers of families and children have had their family law cases resolved with attention to the whole picture of the family, with the goal of resolving the family's legal and underlying non-legal problems. Courts hearing their cases have connected these families and children with services they sorely need. Thousands of self-represented litigants have had access to the family justice system and have received help with their legal and non-legal issues. Courts have understood the need for a strong connection with the community, and judges themselves are viewed as true problem-solvers.

The vision and aim of family justice system reform efforts have made Maryland a national model and leader. ${ }^{38}$ Chief Judge Bell has

35. The Honorable Robert M. Bell, Administration of Justice, 32 MD. B.J. 2, 4 (1999).

36. Id.

37. Id.

38. Maryland's family divisions were showcased at the American Bar Association/University of Baltimore School of Law Center for Families, Children and the Courts Summit on Unified Family Courts in May 1997. See Agenda, Summit on Unified Family Courts: Serving Children and Families Efficiently, Effectively and Responsibly (May 1997) (on file with author). 
left Maryland a remarkable legacy - "the wisdom of a family justice system that invests in early intervention, prevention, and treatment as a means to secure the future well-being of Maryland's children and families." ${ }^{39}$ Family law cases still account for forty-one percent of Maryland's circuit court case filings-more than criminal and other civil cases. ${ }^{40}$ These cases are not going to disappear and are likely to continue to represent the greatest number of circuit court filings in the years ahead.

Thus, it is important for the Maryland judiciary to maintain a focus on family legal issues and to continue to assess the operation of the state's family justice system. Law schools must train students about the therapeutic, ecological family justice paradigm and how to practice effectively within it. The Maryland General Assembly must expand its funding to the judiciary in order to strengthen the progress made relative to the family justice system reform efforts. The justice system must remain sensitive to the changing needs of Maryland's families and children and must adapt and respond to those changes. Each professional whose work touches the family justice system in some way must understand the vulnerability of the families and children who come before the court. We must continue our work on behalf of Maryland's families and children, and we must make Chief Judge Bell proud of our continued accomplishments. It just makes so much sense.

39. BABB \& KUHN, supra note 26 , at 53.

40. MD. JUDICIARY, ANNUAL STATISTICAL ABSTRACT, at CC-5 tbl.CC-1.2 (2011), available at http://www.courts.state.md.us/publications/annualreport/reports/2011/annualreport 2011.pdf. 